\title{
RESEPSI PEMBACA TERHADAP UNSUR PEMBANGUN PUISI AFRIZAL MALNA DALAM ANTOLOGI PUISI BERLIN PROPOSAL
}

\author{
Deden Fahmi Fadilah ${ }^{1}$, Zuriyati ${ }^{2}$, Herlina ${ }^{3}$ \\ Universitas Negeri Jakarta

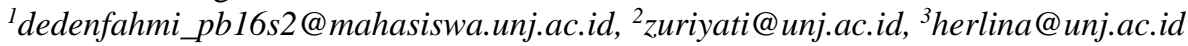

\begin{abstract}
Abstrak
Penelitian ini membahas tentang resepsi atau penerimaan dua puluh orang pembaca dari kalangan Mahasiswa Pendidikan Bahasa Indonesia FKIP Universitas Pakuan terhadap unsur pembangun puisi-puisi kontemporer Afrizal Malna dalam antologi puisi Berlin Proposal. Dari antologi puisi tersebut dipilih enam buah puisi yang dianggap mewakili eksplorasi pembangunan puisi yang ada di keseluruhan buku, yaitu Gerbang Para Dewa, Altar Pergamon, Bungkusan Kesunyian, Berlin Proposal, terltorl dlgltal, dan Paket Kiriman. Penelitian ini fokus terhadap resepsi atau penerimaan para pembaca pada satu kurun waktu terhadap puisi-puisi kontemporer Afrizal Malna dalam antologi puisi Berlin Proposal. Tujuan penelitian ini yaitu untuk memperoleh pemahaman tentang penerimaan atau resepsi pembaca terhadap unsur pembangun puisi-puisi kontemporer Afrizal Malna dalam buku antologi puisi Berlin Proposal. Teori yang digunakan dalam penelitian ini yaitu teori resepsi sinkronik dengan menggunakan metode kualitatif analisis isi. Dari hasil penelitian, dapat disimpulkan bahwa unsur fisik yang paling banyak diresepsi oleh pembaca dari puisi-puisi tersebut yaitu unsur tipografi sebanyak 68 temuan (49,63\%), diksi sebanyak 35 temuan $(25,55 \%)$, kata konkret sebanyak 19 temuan (13,86\%), pengimajian sebanyak 13 temuan $(9,5 \%)$, dan bahasa figuratif sebanyak 2 temuan (1,46\%), sedangkan unsur batin yang paling banyak diresepsi oleh pembaca dari puisi-puisi tersebut yaitu tema sebanyak 50 temuan $(44,247 \%)$, nada dan suasana sebanyak 26 temuan $(23,008 \%)$, amanat sebanyak 21 temuan $(13,86 \%)$, dan perasaan sebanyak 16 temuan $(1,46 \%)$.
\end{abstract}

Kata Kunci: resepsi pembaca, unsur fisik, unsur batin, puisi kontemporer

\begin{abstract}
This study discusses the reception or acceptance of twenty readers from the Indonesian Language Education, Faculty of Teacher Training and Education at Pakuan University on the building elements of contemporary Afrizal Malna poetry in the anthology of Berlin Proposal poetry. From the poetry anthology, six poems were chosen which were considered to represent the exploration of the development of poetry in the entire book, namely the Gerbang Para Dewa, Altar Pergamon, Bungkusan Kesunyian, Berlin Proposal, ter1tor1 d1g1tal, and Paket Kiriman. This study focuses on the reception or acceptance of readers at a period of contemporary Afrizal Malna poems in the anthology of Berlin Proposal poetry. The purpose of this study is to gain an understanding of the reception or reception of the reader to the building elements of contemporary poetry Afrizal Malna in the poetry anthology book Berlin Proposal. The theory used in this research is synchronous reception theory using qualitative content analysis methods. From the results of the study, it can be concluded that the physical elements most readily accepted by the readers of the poems are typography as many as 68 findings (49.63\%), diction as many as 35 findings (25.55\%), concrete words as many as 19 (13.86\%), imagine as many as 13 (9.5\%), and figurative language as many
\end{abstract}


as $2(1.46 \%)$. While the inner elements most read by the readers of these poems are the theme of $50(44.274 \%)$, tone and atmosphere of $26(23.008 \%)$, the mandate of $21(13.86 \%)$, and feelings of $16(1.46 \%)$.

Keywords: reader reception, physical elements, inner elements, contemporary poetry

\section{PENDAHULUAN}

Puisi merupakan salah satu karya sastra yang digandrungi banyak orang di Indonesia. Perkembangan perpuisian modern Indonesia pun sangatlah pesat. Dimulai dari puisi-puisi pra-kemerdekaan yang dipelopori Balai Pustaka, Pujangga Baru, sampai kepada angkatan 45, 50, 66, 2000, dan cyber-sastra. Dari sana, lahir banyak penyari-penyair terkenal Indonesia, seperti Amir Hamzah, Sanusi Pane, Sutan Takdir Alisjahbana, Chairil Anwar, WS Rendra, Sutardji Calzoum Bahri, Sapardi Djoko Damono, Taufik Ismail, Goenawan Mohamad, D. Zawawi Imron, Remy Silado, Afrizal Malna, Acep Zamzam Noor, Hasan Aspahani, sampai Aan Mansyur, Joko Pinurbo. Tangan-tangan penulis inilah yang banyak melahirkan karya-karya puisi yang sangat penting dalam perkembangan puisi modern Indonesia, dari mulai puisi yang bernapas semangat perjuangan, pamflet, romantis, religius, sufistik, sampai kontemporer.

Puisi kontemporer adalah puisi Indonesia yang lahir di dalam waktu tertentu berbentuk dan bergaya tidak mengikuti kaidah-kaidah puisi lama pada umumnya (Purba, 2012: 15). Puisi-puisi kontemporer juga merupakan jenis puisi yang selalu menawarkan hal-hal yang baru. Puisi kontemporer memiliki ciri-ciri nilai dan estetika yang berbeda dengan puisi-puisi pada umumnya. Misalnya, puisi kontemporer tidak hanya terikat pada tema (struktur tematik), tetapi juga terikat kepada struktur fisik puisi (struktur sintaksis). Selain itu, puisi kontemporer dapat dikatakan sebagai hasil eksplorasi seorang penulis puisi terhadap puisi. Beberapa kalangan pun berpendapat bahwa puisi kontemporer juga dapat berupa kejenuhan terhadap puisi-puisi modern konvensional, yang pada akhirnya memunculkan gagasan baru untuk mendefinisikan puisi.

Puisi kontemporer juga merupakan puisi yang ingin keluar dari kebiasaan puisi modern. Puisi kontemporer menginginkan upaya atau dobrakan tersebut dengan gaya eksplorasi yang beragam. Daya eksplorasi tersebut bisa saja berupa eksplorasi dari bentuk puisi, tema puisi, penggunaan kata yang berbeda, bahkan konsep-konsep sintaksis dalam puisi tersebut. Alhasil, puisi kontemporer memiliki tempat tersendiri di hati masyarakat pembaca sebagai khazanah kekayaan dan perkembangan karya sastra, khususnya puisi. Ada beberapa penyair Indonesia yang mengembangkan genre puisi kontemporer, salah satunya adalah Afrizal Malna.

Puisi Afrizal adalah puisi asemik dan puisi konkret yang jenuh pada kebudayaan aksara (Nasrulloh, 2015). Pendapat tersebut merupakan penilaian terhadap puisi-puisi Afrizal dalam buku antologi puisi Berlin Proposal yang dianggap sebagai keterbelengguan Afrizal dalam hal bahasa ketika menulis puisi di Jerman. Afizal seperti ingin mendefinisikan ulang tentang puisi. Di beberapa puisinya, Afrizal seakan tidak mempercayai kata sebagai medium penyampaian pesan dan gagasan di puisinya tersebut, misalnya puisi terltorl dlgltal. Dalam puisi tersebut Afrzial sama sekali tidak menggunakan unsur kata sebagai pembentuk puisinya, tetapi hanya berupa angka-angka dan garis-garis yang akhirnya menyerupai sebuah barcode. Kemudian, dalam puisi Gerbang Para Dewa, terlihat bahwa Afrizal melakukan eksplorasi bentuk puisi menyerupai sebuah gerbang yang disusun dari simbol-simbol bukan kata. Dan dalam 
puisi Bungkusan Kesunyian, Afrizal menyisipkan sebuah gambar atau foto yang memiliki kekuatan makna tersendiri dalam tubuh puisinya. Dengan demikian, beberapa puisi Afrizal Malna dalam buku antologi puisi Berlin Proposal merupakan penawaran baru dalam perpuisian Indonesia. Selain itu, hal itu jugalah yang dianggap salah satu indikasi bahwa puisi-puisi Afrizal ini disebut puisi gelap. Hal itu merupakan sebuah jalan pintas belaka untuk mengidentifikasi puisi-puisi Malna yang sulit dipahami karena tidak bekerja dengan cara yang umum (Crenata, 2018). Cara kerja puisi Afrizal yang dimaksud merupakan bentuk eksplorasi yang dilakukannya terhadap puisi dan hubungannya dengan penerimaan pembaca.

Pembaca dimaksudkan sebagai seseorang yang menerima pesan dan memberi makna sampai menilai sebuah karya sastra. Pendekatan yang demikian itu menggunakan pendekatan pragmatik dengan menggunakan estetika resepsi atau penerimaan. Sebuah teks ditulis untuk dibaca sehingga pembaca memiliki peran vital dalam menyelesaikan sebuah teks dan memberinya identitas baru melalui proses membaca yang dia alami (Ghandehari, 2013). Jadi, penelitian tanggapan ini akan menunjukkan fokus kritis dari seorang pembaca dalam mengalihkan penekanan dari penafsiran yang ditetapkan oleh makna pembaca sebagai bagian penting dalam proses membaca dan penciptaan makna (Trisnawati, 2009).

Dalam penelitian karya sastra khususnya puisi dan unsur pembangunnya, telah ditemukan penelitian dengan menggunakan perspektif tersebut, yaitu "Analisis Stilistika pada Puisi Kepada Peminta-Minta Karya Chairil Anwar (Fransori, 2017). Sebagai kesimpulan dari penelitian tersebut, dapat dikatakan bahwa puisi tersebut menonjolkan berbagai aspek pembentukan kata yang kuat dan tak terduga, dan dari unsur batin, puisi ini menunjukkan sikap sosial yang terjadi pada masyarakat. Dari penelitian tersebut dapat dikatakan bahwa unsur pembangun puisi (fisik dan batin) dapat menjadi suatu kajian yang digunakan untuk membongkar puisi, tetapi pada penelitian tersebut berbeda dengan penelitian ini karena penelitian ini akan membongkar unsur pembangun puisi melalui resepsi pembaca puisi.

\section{Landasan Teori \\ Puisi}

Banyak pengertian puisi yang sudah dikemukakan oleh pakar-pakar sastra, pengertianpengertian yang dibuat biasanya berkaitan dengan etimologi kata 'puisi' dan struktur puisi (fisik atau pun batin). Sebuah puisi adalah sebuah struktur yang terdiri dari unsurunsur pembangun. Unsur-unsur pembangun tersebut dinyatakan bersifat padu karena tidak dapat berdiri sendiri tanpa mengaitkan unsur yang satu dengan unsur yang lainnya. Unsur-unsur dalam sebuah puisi bersifat fungsional dalam kesatuannya dan juga bersifat fungsional terhadap unsur lainnya. Hal tersebut sejalan dengan yang diungkapkan William Wordsworth dan Samuel Coleridg (Wiliams, 2011: 26):

Poetry is the spontaneous overfl ow of powerful feelings: it takes its origin from emotion recollected in tranquillity: the emotion is contemplated till by a species of reaction the tranquillity gradually disappears, and an emotion, kindred to that which was before the subject of contemplation, is gradually produced, and does itself actually exist in the mind.

Dalam pernyataan tersebut dikatakan bahwa puisi adalah luapan spontan dari perasaan yang kuat: emosi itu direnungkan sampai pada titik di saat suatu ketenangan perlahan-lahan menghilang, dan suatu emosi, serupa dengan apa yang ada sebelum subjek 
perenungan, secara bertahap diproduksi, dan apakah itu sendiri benar-benar ada dalam pikiran. Artinya bahwa puisi adalah hasil perenungan, pemikiran, dan manifestasi emosi yang diendapkan dalam teks. Berbeda dengan itu, Situmorang (Purba, 2012) mengatakan bahwa puisi berasal dari bahasa Yunani yaitu Poietis, dan dalam bahasa Latin yaitu Poeta. Arti dari kata itu adalah pembangun, pembentuk, atau pembuat. Asal katanya adalah poieo, atau poio, atau poeo yang artinya membangun, menyebabkan, menimbulkan, atau menyair. Situmorang menyimpulkan pendapatnya tentang fisik puisi yang biasa dibacanya. Pendapat tersebut menjelaskan bahwa pengertian puisi mula-mula dari etimologi 'puisi' kemudian menyimpulkan dari perhatiannya pada perkembangan puisi dalam segi bentuk fisik (Purba, 2012). Seiring waktu berjalan, arti kata itu semakin bergeser menjadi sebuah karya sastra yang kata-katanya disusun menurut irama, sajak, dan kadang-kadang kiasan. Dari pengertian bahwa puisi berisi kata-kata, irama, sajak, dan kiasan, bisa terlihat bagaimana Situmorang membatasi puisi hanya pada struktur pembangun puisi, yaitu kata-kata dan irama dari setiap kata-katanya yang bisa juga memiliki makna kiasan.

\section{Unsur Fisik Puisi}

Puisi disusun dari kata dengan bahasa yang indah dan bermakna dituliskan dalam bentuk bait-bait. Orang dapat membedakan mana puisi dan mana bukan puisi berdasarkan bentuk lahir atau fisik yang terlihat. Berikut ini akan dibahas unsur fisik puisi yang meliputi: diksi, imajinasi, kata konkret, bahasa figuratif, dan tipografi.

a. Diksi (Pilihan Kata)

Pilihan kata berguna untuk membedakan nuansa makna dan gagasan yang ingin disampaikan dan menemukan bentuk yang sesuai dengan situasi dan nilai rasa sebuah puisi. Artinya, kata-katanya merupakan hasil pertimbangan, baik makna, susunan, bunyinya, maupun hubungan kata lain dalam baris dan bait (Bahtiar, Niken Hapsari, Sulistjani, \& Ghulam Ahmad, 2017). Seperti dikatakan di atas puisi memiliki makna masing-masing. Namun, secara umum makna kata dalam puisi digolongkan menjadi dua makna; konotasi dan denotasi. Menurut Alternbernd, makna denotasi sebuah kata adalah definisi kamusnya, yaitu pengertian yang menunjuk benda atau hal yang diberi nama dengan kata itu, disebutkan, atau diceritakan (Pradopo, 2012). Namun, dalam puisi (karya sastra) sebuah kata tidak hanya mengandung makna denotasi saja. Katakata ini harus bersifat konotatif sehingga maknanya bisa saja lebih dari satu (Bahtiar et al., 2017). Kata-kata dalam puisi dipilih dengan mempertimbangkan berbagai aspek estetis dan juga puitis, artinya kata-kata yang dipilih penyair bersifat absolut dan tidak bisa diganti. Berdasarkan uraian di atas dapat disimpulkan bahwa diksi adalah pemilihan kata yang tepat, padat dan kaya akan nuansa makna dan suasana yang diusahakan secermat dan seteliti mungkin dengan mempertimbangkan arti sekecilkecilnya baik makna denotatif, maupun makna konotatif, sehingga mampu memengaruhi imajinasi pembacanya.

b. Pengimajian (Imaji)

Pengimajian dibatasi dengan pengertian kata atau susunan kata-kata yang dapat mengungkapkan pengalaman sensoris seperti penglihatan, pendengaran, dan perasaan. Pilihan serta penggunaan kata-kata yang tepat dapat memperkuat serta memperjelas daya bayang pikiran manusia dan energi tersebut dapat mendorong imajinasi atau daya bayang kita untuk menjelmakan gambaran yang nyata. Gambaran pikiran ini adalah sebuah efek dalam pikiran yang sangat menyerupai atau gambaran yang dihasilkan 
oleh penangkapan kita terhadap sebuah objek yang dapat dilihat, oleh mata, saraf penglihatan, dan daerah-daerah otak yang bersangkutan (Siti dan Syamsuri, 2011).

c. Kata Konkret

Untuk membangkitkan imajinasi pembaca, kata-kata harus dikonkretkan atau dijelaskan (Bahtiar et al., 2017). Maksudnya adalah bahwa kata-kata itu dapat mengarah pada arti secara keseluruhan. Arti menyeluruh dimaksudkan kepada bahwa kata memiliki makna konotasi dan denotasi. Kata konkret akan dipertimbangkan makna denotasinya sebagai pembangun imajinasi pembaca, sedangkan makna konotasi dari kata konkret bisa saja memiliki maksud lain. Jadi, yang dimaksud konkret adalah kata yang dapat menyarankan kepada arti yang menyeluruh. Dengan demikian, pembaca dapat membayangkan secara jelas peristiwa, keadaan, maupun sesuatu yang digambarkan penyair sehingga pembaca dapat memahami arti puisi.

d. Bahasa Figuratif

Bahasa figuratif yaitu penggunaan gaya bahasa oleh penyair untuk melukiskan, mengeluarkan, mengungkapkan perasaan, dan pikiran secara bebas atas puisi tersebut (Bahtiar et al., 2017). Luxemburg menjelaskan bahwa bahasa kias (bahasa figuratif) sering dipandang sebagai ciri khas bagi jenis sastra yang disebut puisi Siti dan Syamsuri, 2011). Pernyataan tersebut menjelaskan bahwa puisi memiliki perbedaan dengan jenis sastra lain karena penggunaan bahasanya yang kias. Jenis sastra lain tidak banyak menggunakan bahasa kias dalam penggunaan bahasanya. Oleh sebab itu, bahasa kias atau bahasa figuratif ini disebut pembeda puisi dari jenis sastra lainnya.

Alberternd menjelaskan bahwa bahasa kiasan bermacam-macam, walau demikian memunyai sifat yang umum, yaitu bahasa-bahasa kiasan tersebut mempertalikan sesuatu dengan cara meghubungkannya dengan yang lain (Siti dan Syamsuri, 2011). Dari pengertian tersebut bisa terlihat bahwa bahasa figuratif juga memiliki peranan penting dalam menyatukan sesuatu makna dengan makna lain untuk memperoleh makna menyeluruh.

e. Tipografi

Salah satu ciri yang membedakan puisi dengan karya sastra lain pada bentuk tulisannya. Melalui indera mata tampak bahwa puisi tersusun atas kata-kata yang membentuk larik-larik puisi. Larik-larik itu disusun ke bawah, tetapi tidak seperti paragraf, dan terikat dalam bait-bait. Tipografi merupakan pembeda yang penting antara puisi dan prosa, serta drama (Walluyo, 1995). Struktur fisik puisi membentuk tipografi yang khas. Tiprografi puisi merupakan bentuk visual yang bisa memberi makna tambahan dan bentuknya bisa didapati pada jenis puisi konkret. Tipografi bentuknya bermacam-macam antara lain berbentuk grafis, kaligrafi, kerucut dan sebagainya. Jadi, tipografi memberikan ciri khas puisi pada periode angkatan tertentu.

\section{Unsur Batin Puisi}

Struktur batin puisi merupakan wacana teks puisi secara utuh yang mengandung arti atau makna yang hanya dapat dilihat atau dirasakan melalui penghayatan. Tanpa penghayatan unsur-unsur puisi yang membangun dari dalam, mustahil dapat memahami puisi secara benar. Struktur batin puisi merupakan isi makna yang sesungguhnya ingin diekspresikan penyair melalui puisinya. Karena struktur batin itu merupakan sesuatu yang tersirat di balik yang tersurat, pembaca harus terlibat secara mendalam, baik fisik, mental maupun pikiran untuk mengetahui atau memahami hakikat makna sebuah puisi yang sesungguhnya. Jadi, unsur puisi juga merupakan wujud kesatuan makna puisi yang berupa pokok pikiran penyair (Bahtiar et al., 2017). Unsur batin puisi pada umumnya ada 
empat, yaitu: tema (sense), perasaan penyair (feeling), nada atau sikap penyair terhadap pembaca (tone), amanat (intention). Berikut ini akan dibahas struktur batin puisi.

a. Tema

Tema merupakan gagasan pokok atau subject-matter yang diungkapkan penyair (Walluyo, 1995). Gagasan pokok bisa diambil oleh penulis dari gagasan-gagasan kehidupan yang menjadi kegelisahan penulis saat menulis puisi. Gagasan-gagasan itu menjadi landasan yang kuat untuk menjadikan sebuah puisi memiliki arti tersendiri bagi pembaca. Tema ini juga yang akan dibekali penulis agar pembaca dapat menginterpretasikan makna puisi yang dibacanya. Kemudian, menurut Kinayati, tema adalah arti yang dikandung dalam bahan atau objek yang dikemukakan penyair kepada pembaca atau penikmat (Bahtiar et al., 2017). Tema menjadi inti pokok pembahasan atau inti dari apa yang ingin disampaikan penulis. Dari bahan dasar yang dimiliki oleh penulis tersebut, puisi akan menjadi hasil pengembangan tema yang dilakukan panulis. Pengembangan tersebut bisa saja dari segi sudut pandang penulis terhadap suatu tema yang dijadikan landasan penulisannya.

b. Perasaan

Perasaan yaitu segala yang dirasakan atau dialami penyair secara imajinatif (Bahtiar et al., 2017). Perasaan penyair dipercaya termanifestasi dalam setiap karya puisinya. Perasaan penyair ini diungkapkan lewat kata-kata yang digunakannya untuk mencapai sikap atau perasaan penyair di dalam puisinya. Dengan kata lain, perasaan penyair dalam puisinya dapat dikenal melalui penggunaan ungkapan-ungkapan yang digunakan dalam puisinya karena dalam menciptakan puisi suasana hati penyair juga ikut diekspresikan dan harus dapat dihayati oleh pembaca (Walluyo, 1995). Jadi, perasaan adalah sikap penyair terhadap pokok persoalan yang ditampilkan dalam puisinya yang merupakan gambaran perasaan yang dialami penyair pada saat menciptakan puisinya.

c. Nada dan Suasana

Menurut Kinayati, nada dalam puisi adalah bagaimana penyair mempunyai sikap terhadap pembaca, misalnya menggurui, menasihati, mengejek, menyindir, dan lainlain (Bahtiar et al., 2017). Pembaca, ketika membaca puisi, sering merasakan seakanakan penulis hadir sedang berbicara pada pembaca dengan sikap tertentu yang dibawanya. Nada dalam puisi pun dapat diketahui dengan memahami apa yang tersurat, yaitu bahasa/ ungkapan-ungkapan yang dipakai dalam puisi. Jadi, nada adalah manifestasi sikap atau sudut pandang tertentu penulis terhadap pembaca yang diungkapkan penulis lewat medium-medium bahasa dalam puisinya.

Suasana adalah keadaan jiwa pembaca (sikap pembaca) setelah membaca puisi (Bahtiar et al., 2017). Suasana ini yang dialami pembaca ketika membaca puisi. Suasana dikaitkan dengan nada yang dibaca puisi dari penulisnya. Jika nada tersebut tersampaikan dengan baik kepada pembaca, pembaca akan mengalami perubahan suasana sesuai dengan nada yang diterimanya dari puisi. Jadi, suasana adalah keadaan jiwa pembaca setelah membaca puisi itu atau akibat psikologis yang ditimbulkan puisi itu terhadap pembaca (Walluyo, 1995)..

d. Amanat

Menurut Kinayati, amanat yaitu hal-hal yang ingin disampaikan penyair kepada pembaca melalui puisinya (Bahtiar et al., 2017). Penyair sebagai sastrawan dan anggota masyarakat baik secara sadar atau tidak merasa bertanggung jawab menjaga kelangsungan hidup sesuai dengan hati nuraninya. Oleh karena itu, puisi selalu ingin mengandung amanat (pesan). Meskipun penyair tidak secara khusus dan sengaja 
mencantumkan amanat dalam puisinya. Amanat tersirat di balik kata dan tema yang diungkapkan penyair. Amanat adalah maksud yang hendak disampaikan penyair melalui puisinya. Amanat berbeda dengan tema. Jika tema berhubungan dengan arti atau maksud penulis, maka amanat adalah makna yang diterima pembaca (Walluyo, 1995). Amanat ini bisa didapatkan pembaca ketika pembaca memahami tema, rasa, nada, dan suasana yang terdapat pada puisi.

\section{METODE PENELITIAN}

Penelitian ini merupakan sebuah kajian analisis isi tanggapan mahasiswa, maka penelitian ini tidak terikat dengan tempat penelitian. Pengambilan data dilakukan di Fakultas Keguruan dan Ilmu Pendidikan, Universitas Pakuan. Adapun waktu pelaksanaan penelitian dilaksanakan bulan September 2018 hingga bulan Oktober 2018. Objek penelitian dalam analisis isi bisa berupa semua jenis komunikasi yang direkam, berupa transkrip wawancara, wacana, protokel observasi, video tape, dokumen (Emzir, 2012). Objek dalam penelitian ini adalah dokumen tertulis berupa data yang berkaitan dengan horizon harapan mahasiswa dalam puisi-puisi kontemporer Afrizal Malna dalam buku antologi puisi Berlin Proposal.

Data utama penelitian ini adalah dokumen tanggapan pambaca terhadap puisi kontemporer Afrizal Malna dalam antologi Berlin Proposal. Data yang dikumpulkan lebih mengambil bentuk kata-kata atau gambar dari pada angka-angka. Sumber data penelitian ini adalah enam buah puisi kontemporer yang dipilih dari antologi puisi Berlin Proposal karya Afrizal Malna. Jumlah responden yang akan diambil tanggapannya adalah 20 mahasiswa. Puisi-puisi yang dipilih untuk menjadi sumber data, yaitu Gerbang Para Dewa, Altar Pergamon, Bungkusan Kesunyian, Berlin Proposal, terltorl dlgltal, dan Paket Kiriman.

Teknik pengumpulan data yang digunakan dalam penelitian ini adalah teknik pengumpulan analisis dokumen. Miles and Huberman (Sugiyono, 2012) mengemukakan bahwa aktivitas dalam analisis data terdiri dari tiga alur kegiatan yaitu data reduction (reduksi data), data display (penyajian data), dan conclusion drawing atau verivication (simpulan atau verifikasi).

\section{HASIL DAN PEMBAHASAN}

Resepsi Pembaca terhadap Unsur Fisik Puisi-Puisi Kontemporer Afrizal Malna dalam Antologi Puisi Berlin Proposal

Unsur fisik merupakan unsur pembangun puisi yang merupakan unsur pembangun yang secara fisik dapat diamati secara langsung. Unsur fisik juga menjadi salah satu pembeda puisi dengan teks lainnya. Pembeda tersebut berasal dari unsur-unsur yang terdapat pada fisik puisi, yaitu pemilihan kata atau diksi, pengimajian, kata konkret, bahasa figuratif, dan tipografi. Unsur-unsur itu membangun puisi dari luar, yaitu dari penampakan puisi yang dapat terlihat sehingga pembaca dapat langsung memahami bahwa suatu teks adalah puisi dari penampakan yang terlihat tersebut. Unsur fisik yang paling banyak diresepsi oleh pembaca dari puisi-puisi tersebut, yaitu tipografi sebanyak 68 temuan $(49,63 \%)$, diksi sebanyak 35 temuan (25,55\%), kata konkret sebanyak 19 temuan $(13,86 \%)$, 
pengimajian sebanyak 13 temuan $(9,5 \%)$, dan bahasa figuratif sebanyak 2 temuan $(1,46 \%)$.

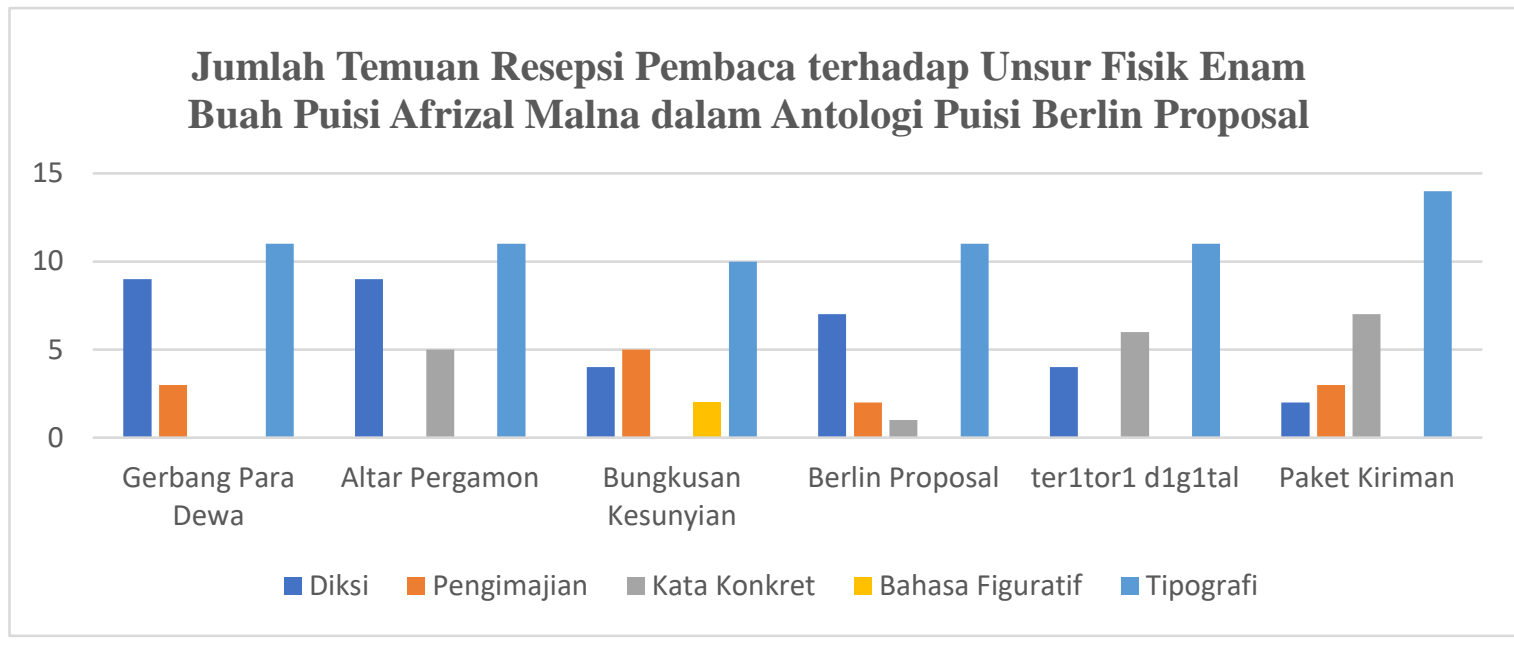

Grafik 1 Resepsi Pembaca terhadap Unsur Fisik Sumber: Dokumen Pribadi

Resepsi pembaca terhadap unsur fisik puisi “Gerbang Para Dewa”

Pembaca meresepsi unsur fisik dalam puisi ini dominan pada unsur tipografi, yaitu 11 temuan. Hal tersebut menunjukkan bahwa pembaca dapat dengan mudah menanggapi bentuk puisi tersebut dengan memperhatikan bentuk puisi sebagai tanda dari penulis tentang pesan yang ingin disampaikannya. Kemudian, pembaca juga meresepsi penggunaan kata dalam puisi tersebut dengan jumlah 9 temuan resepsi pembaca terhadap diksi puisi. Resepsi yang dilakukan pembaca terhadap unsur diksi dalam puisi tersebut terjadi karena banyaknya penggunaan simbol-simbol dalam puisi tersebut dan sedikitnya penggunaan kata dalam puisi. Selanjutnya, pembaca juga meresepsi unsur pengimajian dengan jumlah 3 temuan resepsi pembaca terhadap pengimajian. Sediktinya resepsi pembaca terhadap unsur pengimajian ini menandakan bahwa puisi ini tidak mengedepankan unsur pengimajian yang disisipkan penulis sebagai unsur yang mendorong pembaca dalam memahami puisi ini. Dengan sedikitnya kata, hal tersebut memungkinkan bahwa penulis tidak terlalu mengedepankan pengimajian dalam menciptakan puisi ini. Hal tersebut juga berkaitan pada unsur kata konkret dan bahasa firguratif. Dengan minimnya kata dalam puisi tersebut, maka pembaca juga tidak dapat menerima kedua unsur itu. Oleh sebab itu, tidak ditemukan resepsi pembaca terhadap kata konkret dan bahas figuratif dalam tanggapan tersebut.

Dari hasil pembahasan tersebut dapat dilihat bahwa puisi Gerbang Para Dewa ini ditulis dengan mengedepankan unsur tipografi sebagai sesuatu yang menonjol dari puisi ini. Selain itu, puisi ini terbentuk dari banyak simbol dan sedikit saja kata-kata, sehingga menyebabkan pembaca kurang dapat menerima unsur-unsur yang berkaitan dengan kata seperti pengimajian, kata konkret, bahasa figuratif.

\section{Resepsi pembaca terhadap unsur fisik puisi "Altar Pergamon"}

Resepsi unsur fisik dalam puisi ini yang dominan adalah tipografi, yaitu 11 temuan. Hal tersebut menunjukkan bahwa pembaca dapat dengan mudah menanggapi bentuk puisi tersebut yang dianggap menarik dan memiliki maksud tertentu. Kemudian, pembaca juga meresepsi penggunaan kata dalam puisi tersebut dengan jumlah 9 temuan. Resepsi yang 
dilakukan pembaca terhadap unsur diksi dalam puisi tersebut terjadi karena penggunaan kata-kata yang mudah dikenali dan ditemukan pembaca dalam kehidupan sehari-hari. Selanjutnya, pembaca juga meresepsi unsur kata konkret dengan jumlah 5 temuan resepsi pembaca terhadap kata konkret. Sedikitnya resepsi pembaca terhadap unsur kata konkret ini menandakan bahwa puisi ini tidak mengedepankan unsur kata konkret yang disisipkan penulis sebagai unsur yang mendorong pembaca dalam memahami puisi ini. Hal ini juga disebabkan oleh kata-kata yang digunakan oleh penulis dalam puisi ini tidak banyak mengirimkan sinyal pengimajian. Dengan demikian, hal tersebut juga berkaitan pada unsur pengimajian dan bahasa firguratif. Dengan penggunaan diksi yang berupa labellabel perusahaan media, internet, dan kata-kata yang tidak memiliki struktur sintaksis yang kuat, maka pembaca juga tidak dapat menerima kedua unsur itu. Oleh sebab itu, tidak ditemukan resepsi pembaca terhadap pengimajian dan bahasa figuratif dalam tanggapan tersebut.

Dari hasil pembahasan tersebut dapat dilihat bahwa puisi Altar Pergamon ini ditulis dengan mengedepankan unsur tipografi sebagai sesuatu yang menonjol dari puisi ini. Selain itu, puisi ini terbentuk dari kata-kata yang tidak berbentuk frasa dan hanya berupa nama media, internet, sejarah, dan daerah konflik, menyebabkan pembaca kurang dapat menerima unsur-unsur yang berkaitan dengan kata seperti pengimajian, kata konkret, bahasa figuratif.

\section{Resepsi pembaca terhadap unsur fisik puisi "Bungkusan Kesunyian"}

Resepsi unsur fisik yang dominan dalam puisi ini adalah unsur tipografi, yaitu 10 temuan. Hal tersebut ditunjukan oleh pembaca yang menanggapi sebuah foto atau gambar yang menjadi bagian dari puisi tersebut. Pembaca menanggapi foto atau gambar tersebut sebagai salah satu eksplorasi yang dilakukan penulis dalam penciptaan puisi tersebut. Kemudian, pembaca juga meresepsi penggunaan kata dalam puisi tersebut dengan jumlah 4 temuan. Resepsi yang dilakukan pembaca terhadap unsur diksi dalam puisi tersebut terjadi karena penggunaan kata-kata yang mudah dikenali pembaca dalam kehidupan sehari-hari. Selanjutnya, pembaca juga meresepsi unsur pengimajian dengan jumlah 5 temuan. Resepsi pembaca terhadap unsur pengimajian ini merupakan bentuk resepsi pembaca yang dapat menerima pengimajian dari kata-kata yang digunakan oleh penulis. Sedikitnya resepsi pembaca terhadap unsur diksi dan pengimajian juga berdampak pada unsur bahasa firguratif yang hanya ditemukan sebanyak 2 resepsi. Meskipun penggunaan diksi yang lebih mudah ditemukan dalam kehidupan sehari-hari, tetapi tetap tidak membuat temuan terhadap unsur pengimajian dan bahasa figuratif lebih kuat. Bahkan, tidak ditemukan resepsi pembaca terhadap penggunaan kata konkret dalam puisi tersebut.

Dari hasil pembahasan tersebut dapat dilihat bahwa puisi Bungkusan Kesunyian ini ditulis dengan mengedepankan unsur tipografi sebagai sesuatu yang menonjol dari puisi ini. Selain itu, puisi ini dibangun oleh tiga baris dan sebuah gambar atau foto yang menyebabkan pembaca kurang dapat menerima unsur-unsur yang berkaitan dengan kata seperti pengimajian, kata konkret, bahasa figuratif, tetapi pembaca lebih memperhatikan dominasi foto atau gambar dalam meresepsi puisi tersebut.

\section{Resepsi pembaca terhadap unsur fisik puisi "Berlin Proposal"}

Penggunaan kata dalam puisi tersebut cukup banyak, tetapi pembaca meresepsi unsur fisik dalam puisi ini dominan pada unsur tipografi, yaitu 11 temuan. Hal tersebut ditunjukan oleh pembaca, menanggapi bentuk puisi yang memiliki perbedaan dengan puisi pada umumnya, yaitu berbentuk rata kanan dan kiri. Pembaca menanggapi bentuk 
tersebut dengan mengatakan lebih mirip dengan sebuah paragraf dan tidak berbentuk baitbait. Kemudian, pembaca juga meresepsi penggunaan kata dalam puisi tersebut dengan jumlah 7 temuan resepsi pembaca terhadap diksi puisi. Resepsi yang dilakukan pembaca terhadap unsur diksi dalam puisi tersebut terjadi karena penggunaan kata-kata yang mudah dikenali dan ditemukan pembaca dalam kehidupan sehari-hari. Selanjutnya, pembaca juga meresepsi unsur pengimajian dengan jumlah 2 temuan. Resepsi pembaca terhadap unsur pengimajian ini merupakan penerimaan terhadap pengimajian dari katakata yang digunakan oleh penulis. Sedikitnya resepsi pembaca terhadap unsur diksi dan pengimajian juga berdampak pada unsur kata konkret yang hanya ditemukan sebanyak 1 resepsi, dan tidak terdapat resepsi pembaca terhadap unsur bahasa figuratif. Meskipun penggunaan diksi yang lebih mudah temukan dalam kehidupan sehari-hari, tetapi tetap tidak membuat temuan terhadap unsur pengimajian dan bahasa figuratif juga lebih kuat.

Dari hasil pembahasan tersebut dapat dilihat bahwa puisi Berlin Proposal ini ditulis dengan mengedepankan unsur tipografi sebagai sesuatu yang menonjol dari puisi ini. Selain itu, meskipun puisi ini dibangun oleh kata-kata atau kalimat yang dapat dimengerti pembaca dengan bentuk rata kanan dan kiri ini tetap membuat pembaca kurang dapat menerima unsur-unsur yang berkaitan dengan kata seperti pengimajian, kata konkret, bahasa figuratif.

\section{Resepsi pembaca terhadap unsur fisik puisi "ter1tor1 d1g1tal"}

Terhadap puisi ini, pembaca meresepsi unsur fisik dengan dominasi pada unsur tipografi yaitu 11. Hal tersebut ditunjukan oleh pembaca yang menanggapi bentuk puisi yang memiliki perbedaan dengan puisi pada umumnya, yaitu berbentuk seperti barcode yang dibangun oleh garis-garis dan angka-angka. Kemudian, pembaca juga meresepsi penggunaan kata dalam puisi tersebut dengan jumlah 4 temuan resepsi pembaca terhadap diksi puisi. Resepsi yang dilakukan pembaca terhadap unsur diksi dalam puisi tersebut terjadi karena penggunaan angka-angka yang dianggap sebagai pengganti kata. Sejatinya, tidak terdapat kata dalam puisi ini, tetapi angka-angka tersebut berposisi sebagai pengganti kata-kata yang secara sengaja dituliskan oleh penulisnya. Selanjutnya, pembaca juga meresepsi unsur kata konkret dengan jumlah 6 temuan. Tidak terdapatnya kata dalam puisi tersebut menyebabkan bahwa temuan terhadap kata konkret ini merupakan resepsi pembaca terhadap angka-angka yang dapat dengan mudah dikonkretkan sebagai sesuatu yang memiliki makna tertentu. Kemudian, tidak ditemukan resepsi pembaca terhadap pengimajian dan bahasa figuratif dalam puisi ini. Hal tersbeut diakibatkan oleh ketiadaan kata dalam puisi tersebut sehingga pembaca tidak menerima imaji dalam puisi tersebut serta pembaca tidak menerima bahasa figuratif dalam puisi tersebut.

Dari hasil pembahasan tersebut dapat dilihat bahwa puisi "ter1tor1 d1g1tal" ini ditulis dengan mengedepankan unsur tipografi sebagai sesuatu yang menonjol. Puisi ini memiliki bentuk yang unik dengan garis-garis dan angka yang akhirnya menyerupai sebuah barcode. Pada unsur kata konkret, pembaca menggantikan peran kata yang bermakna dengan angka-angka yang bermakna karena pembaca juga menganggap angkaangka tersebut sebagai suatu pengganti kata dalam puisi tersebut. Selain itu, karena puisi ini dibangun oleh garis-garis dan angka dengan meniadakan kata dalam puisi tersebut akhirnya menyebabkan pembaca kurang dapat menerima unsur-unsur yang berkaitan dengan kata seperti pengimajian dan bahasa figuratif. 


\section{Resepsi pembaca terhadap unsur fisik puisi "Paket Kiriman"}

Unsur fisik yang dominan dalam puisi ini adalah unsur tipografi, yaitu 14. Hal tersebut ditunjukan oleh pembaca yang menanggapi bentuk puisi yang memiliki perbedaan dengan puisi pada umumnya, yaitu berbentuk seperti jam pasir yang lebar di bagian atas kemudian mengerucut di bagian tengah dan kembali melebar di bagian bawah. Kemudian, pembaca juga meresepsi penggunaan kata dalam puisi tersebut dengan jumlah 2 temuan. Resepsi yang dilakukan pembaca terhadap unsur diksi yaitu berupa tanggapan bahwa diksi yang digunakan dalam puisi ini merupakan kata-kata dalam sehari-hari, tetapi menceritakan sebuah peristiwa sejarah. Dari kata-kata yang digunakan oleh penulis, pembaca dapat meresepsi pengimajian yang terdapat dalam puisi ini sebanyak 3 resepsi. Pengimajian yang diterima pembaca berupa indera penglihatan. Selanjutnya, pembaca juga meresepsi unsur kata konkret dengan jumlah 7. Resepsi pembaca terhadap kata konkret dalam puisi ini berupa kemampuan pembaca dalam memaknai setiap kata yang dirangkai menjadi sebuah peristiwa sejarah, khususnya sejarah yang ada di Jerman. Dengan demikian, pembaca dapat melihat konkretisasi kata yang terdapat dalam puisi tersebut, meskipun jumlah pembaca yang meresepsinya terbilang tidak banyak. Kemudian, pembaca juga dapat meresepsi terhadap bahasa figuratif dalam puisi ini. Hal tersebut diakibatkan oleh ketiadaan kata yang digunakan sebagai makna kias sehingga pembaca tidak menerima bahasa figuratif dalam puisi tersebut.

Dari hasil pembahasan tersebut dapat dilihat bahwa puisi "Paket Kiriman" ini ditulis dengan mengedepankan unsur tipografi sebagai sesuatu yang menonjol dari puisi ini, yaitu berupa kata-kata atau kalimat yang disusun menyerupai jam pasir dengan bentuk lebar di bagian atas kemudian mengerucut di bagian tengah dan kembali melebar di bagian bawah. Kata-kata atau diksi yang digunakan merupakan kata-kata sehari-hari. Dengan jelas pembaca dapat mengonkretkan kata tersebut sebagai peristiwa sejarah yang terjadi di Jerman. Selain itu, karena puisi ini dibangun oleh kata yang minim dengan makna kias dan hanya berupa kata-kata yang menyuratkan peristiwa sejarah, maka menyebabkan pembaca kurang dapat menerima unsur-unsur yang berkaitan dengan kata seperti pengimajian dan bahasa figuratif.

\section{Resepsi Pembaca terhadap Unsur Batin Puisi-puisi Kontemporer Afrizal Malna dalam Antologi Puisi Berlin Proposal}

Unsur batin merupakan wacana teks puisi secara utuh yang mengandung arti atau makna yang hanya dapat dilihat atau dirasakan melalui penghayatan. Unsur batin juga disebut merupakan pikiran perasaan yang diungkapkan penyair (Walluyo, 1995). Dengan demikian unsur batin hanya dapat dirasakan, tetapi tidak dapat dilihat. Butuh penghayatan untuk mendapatkan kedalaman batin puisi, bagi pembaca. Unsur batin juga sering dikatakan sebagai unsur pembangun puisi yang berasal dari dalam puisi. Artinya, butuh penggeledahan untuk menemukannya karena unsur batin tidak tampak secara fisik. Unsur batin yang paling banyak diresepsi oleh pembaca dari puisi-puisi tersebut yaitu tema sebanyak 50 temuan (44,247\%), nada dan suasana sebanyak 26 temuan $(23,008 \%)$, amanat sebanyak 21 temuan $(13,86 \%)$, dan perasaan sebanyak 16 temuan $(1,46 \%)$. Berikut ini sebaran temuan unsur batin di enam buah puisi tersebut. 


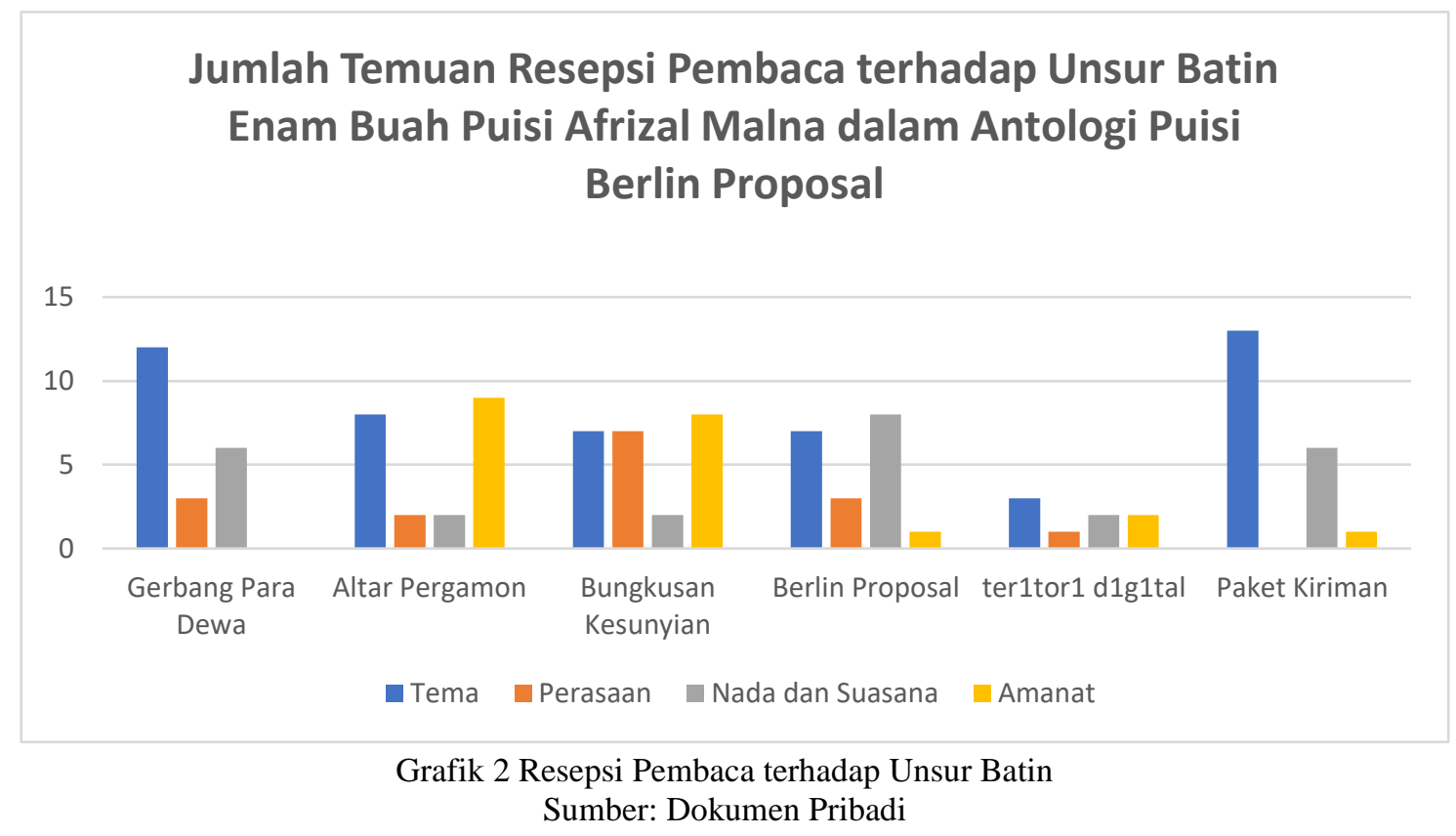

\section{Resepsi pembaca terhadap unsur batin puisi "Gerbang Para Dewa"}

Pembaca meresepsi unsur batin dalam puisi ini dominan pada unsur tema yaitu 12 . Hal tersebut menunjukkan bahwa pembaca dapat dengan mudah menanggapi tema sebagai gagasan pokok tentang pesan yang ingin disampaikan penulis, yaitu berupa penggambaran akan peperangan dan sesuatu peristiwa sejarah yang terjadi di gerbang Ishtar Gate. Kemudian, pembaca juga meresepsi perasaan dalam puisi tersebut dengan jumlah 3 temuan. Resepsi yang dilakukan pembaca terhadap unsur perasaan dalam puisi tersebut terjadi karena pembaca menerima bagaimana perasaan pembaca yang merasa $n g e r i$ ketika menulis puisi tersebut. Selanjutnya, pembaca juga meresepsi unsur nada dan suasana dengan jumlah 6 temuan. Penerimaan pembaca terhadap nada dan suasana tersebut terjadi karena pembaca menemukan nada-nada yang disisipkan pembaca dalam puisi tersebut berupa nada cerita kengerian dan menyebabkan pembaca mengalami suasana ngeri yang sama. Namun, terhadap puisi ini, pembaca tidak meresepsi pesan amanat yang ingin disampaikan oleh penulis pada pembaca melalui puisi tersebut.

Dari hasil pembahasan tersebut dapat dilihat bahwa puisi "Gerbang Para Dewa" ini ditulis dengan mengedepankan unsur tema sebagai sesuatu yang menonjol dari puisi ini. Sebagian besar pembaca dapat menerima tema yang melandasi puisi tersebut. Selain itu, pembaca dapat meresepsi perasaan penulis dalam puisi tersebut dan menerima nada dan suasana yang dimunculkan dalam puisi, meskipun jumlahnya hanya sebagian kecil. Kemudian, pembaca tidak dapat menerima pesan amanat yang terdapat dalam puisi tersebut.

\section{Resepsi pembaca terhadap unsur batin puisi “Altar Pergamon"}

Pembaca meresepsi unsur batin dalam puisi ini dominan pada unsur amanat yaitu 9 temuan. Hal tersebut menunjukkan bahwa pembaca dapat dengan mudah menerima amanat yang ingin di sampaikan oleh penulis. Amanat yang diterima tersebut berupa kehidupan tidak lepas dari pengaruh media, internet, dan perusahaan-perusahaan tersebut yang kemudian memberikan pengaruh pada contoh besar peristiwa seperti konflik di jalur Gaza. Kemudian, pembaca juga meresepsi tema dari puisi tersebut dengan jumlah 8 temuan. Resepsi yang dilakukan pembaca terhadap unsur tema dari puisi tersebut terjadi 
karena pembaca menerima gagasan pokok yang menjadi landasan dari puisi tersebut, yaitu tentang teknologi. Selanjutnya, pembaca juga meresepsi perasaan dan dengan jumlah 2 temuan. Resepsi pembaca terhadap perasaan berupa penerimaan bagaimana perasaan penulis ketika menulis puisi ini yaitu berupa perasaan empati. Penerimaan pembaca terhadap nada dan suasana dalam puisi ditemukan dengan jumlah 2 temuan. Resepsi terhadap nada dan suasana yang dimunculkan dalam puisi ini terjadi karena pembaca dapat menerima nada simpati yang disisipkan penulis sehingga pembaca juga ikut dalam suasana simpati yang sama.

Dari hasil pembahasan tersebut dapat dilihat bahwa puisi "Altar Pergamon" ini ditulis dengan mengedepankan unsur amanat sebagai sesuatu yang menonjol dari puisi ini. Sebagian besar pembaca dapat menerima amanat yang menjadi pesan bagi pembaca dari penulis melalui puisi tersebut. Selain itu, pembaca dapat meresepsi tema puisi tersebut dengan cukup baik, tema yang menonjol dari puisi tersebut yaitu berupa gagasan tentang peran teknologi dalam kehidupan. Kemudian, pembaca juga dapat meresepsi perasaan penulis dalam puisi tersebut dan menerima nada dan suasana yang dimunculkan, meskipun jumlahnya hanya sebagian kecil, yaitu berupa perasaan simpati dan nada serta suasana simpati.

\section{Resepsi pembaca terhadap unsur batin puisi "Bungkusan Kesunyian"}

Unsur yang dominan dalam puisi ini adalah amanat yaitu 8 temuan. Hal itu menunjukkan bahwa pembaca dapat dengan mudah menerima amanat yang ingin di sampaikan oleh penulis. Amanat yang diterima tersebut berupa kehidupan tidak lepas dari pengaruh hukum dalam setiap aspek kehidupan. Kemudian, pembaca juga meresepsi tema dari puisi tersebut dengan jumlah 7 temuan. Resepsi yang dilakukan pembaca terhadap unsur tema dari puisi tersebut terjadi karena pembaca menerima gagasan pokok yang menjadi landasan dari puisi tersebut, yaitu tentang hukum yang tengah ditegakan. Selanjutnya, pembaca juga meresepsi perasaan dengan jumlah 7 . Resepsi pembaca terhadap perasaan dalam puisi tersebut berupa penerimaan bagaimana perasaan penulis ketika menulis puisi ini yaitu berupa perasaan sunyi. Penerimaan pembaca terhadap nada dan suasana dalam puisi ditemukan dengan jumlah 2 temuan. Resepsi terhadap nada dan suasana yang dimunculkan dalam puisi ini terjadi karena pembaca dapat menerima nada cerita kesunyian yang disisipkan penulis sehingga pembaca juga ikut dalam suasana sunyi yang sama, meskipun hanya dari sebagian kecil pembaca yang menerimanya.

Dari hasil pembahasan tersebut dapat dilihat bahwa puisi "Bungkusan Kesunyian" mengedepankan unsur amanat dan hal itu dapat diterima oleh pembaca. Selain itu, pembaca dapat meresepsi tema puisi tersebut dengan cukup baik dengan menemukan tema yang menonjol yaitu berupa gagasan tentang peran hukum dalam kehidupan. Kemudian, pembaca juga dapat meresepsi perasaan penulis dalam puisi tersebut dan menerima nada dan suasana yang dimunculkan, meskipun jumlahnya hanya sebagian kecil, yaitu berupa perasaan sunyi dan nada cerita kesunyian serta suasana sunyi pula yang diterima pembaca.

\section{Resepsi pembaca terhadap unsur batin puisi "Berlin Proposal"}

Dalam puisi ini dominan pada unsur nada dan suasana yaitu 8 temuan. Artinya, pembaca dapat dengan mudah menerima nada dari penulis yang berpengaruh pada suasana pembaca. Nada yang diterima tersebut berupa cerita penulis yang mengalami kerumitan dan keterbatasan ketika berada di Berlin sehingga pembaca menerima permasalahan tersebut sebagai suasana yang seperti dialami oleh penulis. Kemudian, pembaca juga 
meresepsi tema dari puisi tersebut dengan jumlah 7 temuan. Unsur tema dari puisi tersebut terjadi karena pembaca menerima gagasan pokok yang menjadi landasan dari puisi tersebut, yaitu tentang peristiwa di Berlin dan hubungannya dengan dunia luar. Selanjutnya, pembaca juga meresepsi perasaan dan dengan jumlah 3 temuan. Perasaan dalam puisi tersebut berupa penerimaan bagaimana penulis ketika menulis puisi ini yaitu berupa perasaan kebingungan. Penerimaan pembaca terhadap amanat dalam puisi ditemukan dengan jumlah 1 temuan. Resepsi terhadap amanat yang diterima pembaca dari puisi ini terjadi karena pembaca dapat menerima pesan yang ingin disampaikan oleh penulis melalui puisinya tersebut.

Dari hasil pembahasan tersebut dapat dilihat bahwa puisi "Berlin Proposal" ini ditulis dengan mengedepankan unsur nada dan suasana sebagai sesuatu yang menonjol dari puisi ini. Selain itu, pembaca dapat meresepsi tema puisi tersebut dengan cukup baik, yaitu berupa gagasan tentang kehidupan di Berlin dan kaitannya dengan kehidupan dunia luar. Kemudian, pembaca juga dapat meresepsi perasaan penulis yaitu bagaimana perasaan penulis yang merasa kebingungan dan merasa terbatas ketika berada di Berlin. Sebagian besar pembaca juga tidak dapat menerima pesan amanat yang disampaikan penulis lewat puisinya karena hanya sebagian kecil pembaca saja yang dapat menerima amanat dari puisi tersebut.

\section{Resepsi pembaca terhadap unsur batin puisi "ter1tor1 d1g1tal"}

Temuan resepsi pembaca terhadap unsur batin dalam puisi ini berjumlah 8 temuan. Data temuan tersebut dibagi menjadi 3 temuan, 1 temuan resepsi pembaca terhadap perasaan, 2 temuan resepsi pembaca terhadap nada dan suasana, 2 temuan resepsi pembaca terhadap amanat puisi. Hal tersebut menandakan bahwa pembaca tidak dapat meresepsi unsur batin puisi dengan baik. Hal tersebut dikarenakan puisi yang tidak memiliki kata dan sulit ditemukan unsur-unsur batin puisinya.

\section{Resepsi pembaca terhadap unsur batin puisi “Paket Kiriman"}

Temuan resepsi pembaca terhadap unsur batin dalam puisi ini berjumlah 20 temuan. Data temuan tersebut dibagi menjadi 13 temuan resepsi pembaca terhadap tema puisi, 6 temuan resepsi pembaca terhadap nada dan suasana, 1 temuan resepsi pembaca terhadap amanat puisi. Kemudian, tidak ditemukan resepsi pembaca terhadap perasaan tersebut. Puisi tersebut merupakan puisi yang memiliki banyak kata dan merupakan penggambaran peristiwa sejarah yang terjadi di Jerman. Puisi tersebut menyerupai seperti jam pasir dengan bentuk lebar di bagian atasnya kemudian mengerucut ke dalam di bagian tengah dan kembali melebar di bagian bawah. Pembaca meresepsi unsur batin dalam puisi ini dominan pada unsur tema yaitu 13 temuan. Tema yang diterima tersebut berupa gagasan tentang penyampaian peristiwa sejarah, khususnya sejarah di Jerman. Kemudian, pembaca juga meresepsi nada dan suasana dalam puisi dengan ditemukannya 6 temuan. Resepsi terhadap nada dan suasana yang dimunculkan dalam puisi ini terjadi karena pembaca dapat menerima nada cerita peristiwa sejarah yang disisipkan penulis sehingga pembaca juga ikut dalam suasana cerita yang sama. Selanjutnya, sebagian kecil pembaca dapat menresepsi unsur amanat yang terdapat dalam puisi tersebut dengan jumlah 1 temuan terhadap amanat. Resepsi terhadap amanat tersebut terungkap dengan diterimanya amanat berupa peringatan tentang jangan melupakan sejarah. Pada unsur perasaan, tidak terdapat pembaca yang meresepsi penjabaran peristiwa sejarah Jerman dan sisipan perasaan penulis ketika menciptakan puisi tersebut. 
Dari hasil pembahasan tersebut dapat dilihat bahwa puisi "Paket Kiriman" ini ditulis dengan mengedepankan unsur tema sebagai sesuatu yang menonjol dari puisi ini. Sebagian besar pembaca dapat menerima tema sejarah yang menjadi gagasan pokok puisi tersebut. Selain itu, pembaca dapat meresepsi nada dan suasana puisi tersebut dengan cukup baik, yaitu nada bercerita penulis yang menyebabkan pembaca mengalami suasana seperti pada cerita tersebut. Kemudian, pembaca juga dapat meresepsi amanat dalam puisi tersebut meskipun jumlahnya hanya sebagian kecil, yaitu berupa peringatan jangan melupakan sejarah. Terakhir, pembaca tidak dapat meresepsi perasaan penulis dalam puisi tersebut.

\section{SIMPULAN}

Dari hasil pembahasan tersebut maka dapat disimpulkan bahwa unsur fisik yang paling banyak diresepsi oleh pembaca dari puisi-puisi tersebut yaitu unsur tipografi sebanyak 68 temuan (49,63\%), diksi sebanyak 35 temuan (25,55\%), kata konkret sebanyak 19 temuan $(13,86 \%)$, pengimajian sebanyak 13 temuan $(9,5 \%)$, dan bahasa figuratif sebanyak 2 temuan $(1,46 \%)$. Data tersebut membuktikan bahwa puisi-puisi tersebut menonjolkan eksplorasi pada bentuk tipografi sebagai salah satu unsur fisik yang paling banyak diresepsi. Hal tersebut kemudian membuktikan bahwa puisi-puisi tersebut tidak memunculkan eksplorasi dalam hal penggunaan gaya bahasa atau bahasa figuratif yang biasa ditemukan dalam puisi-puisi biasanya. Puisi-puisi tersebut cenderung mengedepankan penyampaian pesan bukan dari penggunaan kata-kata konkret, atau pengimajian, apalagi melalui bahasa-bahasa figuratifnya. Unsur batin yang paling banyak diresepsi oleh pembaca dari puisi-puisi tersebut yaitu tema sebanyak 50 temuan $(44,247 \%)$, nada dan suasana sebanyak 26 temuan $(23,008 \%)$, amanat sebanyak 21 temuan $(13,86 \%)$, dan perasaan sebanyak 16 temuan $(1,46 \%)$. Dengan demikian, penulis lebih banyak mengeksplorasi unsur tema, dan nada dan suasana dalam puisi-puisi ini ketimbang mengedepankan unsur perasaan dan amanat dalam puisi-puisinya.

Menurut resepsi pembaca tersebut, maka dapat disimpulkan bahwa keenam puisi kontemporer karya Afrizal Malna yang dipilih dari antologi puisi Berlin Proposal yaitu, Gerbang Para Dewa, Altar Pergamon, Bungkusan Kesunyian, Berlin Proposal, terltor 1 dlgltal, dan Paket Kiriman, merupakan puisi hasil eksplorasi penulisnya dalam unsur pembangun puisinya. Dari segi unsur fisik puisi, penulis banyak mengeksplorasi tipografi dan diksi ketimbang unsur fisik yang lain. Dalam unsur batin puisi, penulis melakukan pengembangan tema dan nada dan suasana.

\section{DAFTAR PUSTAKA}

Bahtiar, A., Hapsari, S. N., Sulistjani, E., \& Ahmad, M. G. (2017). Kajian puisi. Tangerang: Pustaka Mandiri.

Crenata, A. K. (2018). Masalah (Krusial) puisi kontemporer kita? Retrieved April 11, 2019, from https://jurnalruang.com/read/1541499687-masalah-krusial-puisikontemporer-kita

Emzir. (2012). Metodologi penelitian kualitati. Jakarta: Penerbit Rajawali Press.

Fransori, A. (2017). Analisis stilistika pada puisi kepada peminta-minta karya Chairil Anwar. DEIKSIS, 09(01), 1-12. https://doi.org/http://dx.doi.org/10.30998/deiksis .v9i01.884 
Ghandehari, S. (2013). Definition of reader, as a relative concept, in reader- response theories. Procedia Social and Behavioral Sciences, 70, 1391-1388. https://doi.org/doi: 10.1016/j.sbspro.2013.01.20

Nasrulloh, Z. (2015). "Berlin proposal": Mesin pemecah enigma. Retrieved from http://www.buruan.co/berlin-proposal-mesin-pemecah-enigma/

Pradopo, R. D. (2012). Pengkajian puisi. Yogyakarta: UGM Press.

Purba, A. (2012). Sastra Indonesia kontemporer. Yogyakarta: Graha Ilmu.

Siti, A. A., \& Syamsuri, A. S. (2011). Apresiasi dan kajian puisi. Surabaya: Penerbit Bintang.

Sugiyono. (2012). Metode penelitian kuantitatif, kualitatif, dan R\&D. Bandung: Alfabeta.

Trisnawati, R. K. (2009). Implementing reader-response theory: An alternative way of teaching literature research report on the reading of booker T Washington's up from slavery. JEE, Journal of English and Education, 3(1), 1-14. Retrieved from https://www.researchgate.net/publication/312554785

Walluyo, H. J. (1995). Teori dan apresiasi puisi. Bandung: Angkasa.

Wiliams, N. (2011). Contemporary poetry. Edinburgh: Edinburgh University Press. Retrieved from www.euppublishing.com 